\title{
Commemorative Lecture on the Occasion of Medical University of Vienna's "Dies Academicus" and Announcement of Elsevier's Donation of the Pernkopf Atlas Anatomical Illustrations to the Josephinum
}

\author{
Christiane Druml, LL.D.
}

OPEN ACCESS

March 12, 2021 (Translated and slightly edited from the German original)

Your Magnificence, ladies and gentlemen!

We are gathered here today, on this momentous occasion of March 12, to commemorate all those who were victimized by the National Socialist regime in Austria. These are not only the - above all - Jewish members of the University of Vienna, who were dismissed, expelled, murdered. No, these are also others who had to suffer injustice in connection with the university.

I would like to draw the arc wider here and remember those who were victimized in connection with anatomy. People who were executed in Vienna and whose bodies became the model and basis for the anatomical drawings of the "Atlas of Topographical and Applied Human Anatomy" by Eduard Pernkopf. It is now believed that the models for the illustrations, made between 1938 and 1945, came from a number of 1377 corpses of opponents of the regime, including resistance fighters, executed in the Criminal Court in Vienna, including 7 Jews. We do not know which of these individual bodies were used to produce the drawings.

As a reminder, Eduard Pernkopf - an ardent National Socialist - was professor of anatomy from 1933, the very year he also joined the NSDAP. From 1938 he was dean and from 1943 rector of the University of Vienna. He was responsible for the implementation of National Socialist ideology in the medical curriculum.

After the end of the war he was dismissed in 1945 and - like so many others - after internment in Salzburg as part of denazification procedures, subsequently returned to the University of Vienna and from then on devoted himself to working on his anatomy atlas. This was the time of the "great silence." The historical role of the anatomy institutes at the three medical faculties in Austria was concealed and covered up. It would be even longer before this silence was broken.

Pernkopf died in 1955. The atlas, however, remained and continued to be produced, offered for sale, and used in many countries around the world and in many translations. It was a widely recognized work of extreme precision and quality of illustration.

It was only in 1985 that Pernkopf's close connection to National Socialism became an international topic. Simon Wiesenthal also played a role at that time, and ultimately only an official request from Yad Vashem led to an internal Austrian reappraisal, which was carried out by a Senate Commission of the University of Vienna and finally published in 1998 under the name "Anatomical Sciences 1938-1945" with great public - also international - attention. At the same time, however, a debate arose about what should be done with the atlas. The situation was different from that of various other medical-scientific work produced in connection with Nazi crimes, which had no scientific value whatsoever.

The atlas, as I said, is a work of high quality and even its greatest critics think that it has a mission to fulfill: on the one hand, as some argue, the drawings, due to their immense accuracy and goodness, can serve as a template for the most difficult medical interventions and thus save human lives, on the other hand, they remind us of those people who fell victim to the Nazi system through their execution. The drawings appeal to us to remember them. 
They warn us and admonish us of the often unfortunate connections between medicine and power, between science and political rule. They ask us to be on our guard, and they call us to keep all this in mind and to remember the victims.

The atlas is a book that continues to spark debate about how to deal with unethically acquired results in science. This debate also continues to be important to us and continues today.

In the fall of 2019, the major scientific publisher Elsevier, as the legal successor to the original publisher of the atlas Urban and Schwarzenberg, approached us - the Josephinum as the home of the medical collections, and thus the Medical University of Vienna itself - and gave us the original drawings and other documents still in its possession as part of a donation. Elsevier's wish was to return the documents and original illustrations to their place of origin for preservation and scientific processing.

Now it is our task to manage and care for the ethical and scientific dimension of these important contemporary historical and anatomical documents. With Herwig Czech as successor to Michael Hubenstorf as Professor of Medical History and thus one of the most renowned experts in the field of contemporary medical history, and our outstanding team of conservators, we are in an excellent position to deal with the ethical, historical and also the numerous conservational issues that always arise anew, while at the same time restoring personality and dignity to the victims.

Our engagement with medicine's past, and thus selfreflection, remains essential. The examination of Nazi medicine is therefore far from over, although some would wish it to be, and we are endeavoring to set a special focus here at MedUni Vienna.

It was already planned last March together with Elsevier to make an event on the occasion of this generous donation to us. Corona intervened - as we all know - and prevented it. However, we can think of no better occasion for a broader announcement of this cooperation than today, March 12, the University's Memorial Day, to remember here those who lost their lives in a regime of injustice.

May they rest in peace.

\begin{abstract}
About the Author
Christiane Druml, LL.D., studied law at the University of Vienna. She holds the UNESCO Chair on Bioethics at the Medical University of Vienna and serves as Director of Ethics, Collections and History of Medicine at the Medical University of Vienna since 2016. Since the foundation of the Ludwig Boltzmann-Institute for Rare and Undiagnosed Diseases in 2016, she acts as Deputy Director and key researcher of the Bioethics Research Group. In 2007, she was appointed as President of the Austrian National Bioethics Commission by the Austrian Federal Chancellor. She is a member of the Corona Task Force of the Federal Minister of Social Affairs, Health, Care and Consumer Protection of the Republic of Austria and serves furthermore in many international functions.
\end{abstract}

\section{Christiane Druml, LL.D.}

Medical University of Vienna, Department of Ethics, Collections, and History of Medicine (Josephinum)

Contact: christiane.druml@meduniwien.ac.at

\section{Licensing}

The author has chosen to license this content under a Creative Commons Attribution, NonCommercial, NoDerivatives 4.0 International License.

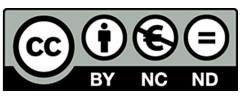

Image Credit. The photo of the Josephinum was approved for use in this Special Issue by the Josephinum - Ethics, Collections and History of Medicine, MedUni Vienna.

\section{Conflict of Interest Statement}

The Journal of Biocommunication Management Board and Editors believe that transparency in academic research is essential. Our $J B C$ authors are now required to disclose any conflict of interest when submitting a manuscript. In accordance with the $J B C$ 's editorial policy, no potential conflict of interest has been reported or declared by this author. 